\title{
12 Dicas para o calouro no primeiro ano da FMUSP
}

\section{Twelve tips for newcomer USP Medical School students}

\author{
Luiz Fernando Ferraz da Silva (Burns)
}

\section{INTRODUÇÃO}

No momento em que inicio a escrita deste " 12 Dicas Para", que considero muito especial, me permito o que considero um privilégio: ficar por umas poucas horas sentado à beira de um lago,numa agradável temperatura de $2{ }^{\circ} \mathrm{C}$ com um chá quente do lado, e voltando mentalmente a 1997 (quando era calouro desta Casa). Pensando em tudo que vi naquele ano, e nos anos subseqüentes, seguem as minhas 12 dicas para literalmente "enfrentar" essa nova fase e "sobreviver" ao primeiro ano, didaticamente divididas em dicas mais conceituais - quase conselhos - e dicas mais práticas para o dia-a-dia. Vamos a elas:

1. Nenhum ser humano é onipotente: Embora pareça um clichê desnecessário, ter isso em mente é vital para qualquer um (especialmente o calouro) porque ao longo deste ano será fundamental aprender a lidar com pessoas diferentes e também com suas próprias questões individuais e existenciais - que são muitas devido à grande carga de novidades da vida acadêmica. Lembrem-se ninguém tem todas as respostas (felizmente), ninguém está sozinho e todos precisam de ajuda de outras pessoas sempre - admitir isto é virtude e não fraqueza. Não hesite em pedir ajuda a seus familiares, amigos, veteranos, professores, tutores, enfim, a qualquer pessoa com quem você tenha uma relação de confiança.

2. Organize o tempo: Você verá que cada vez mais este será um bem escasso e precioso. Frente à infinidade de atividades curriculares e extracurriculares de pesquisa e extensão existentes, lembre-se de que é IMPOSSÍVEL fazer tudo. Seja seletivo e saiba dizer "não". Para facilitar, periodicamente pegue um calendário semanal e faça uma lista de todas as coisas que lhe interessam ou que você precisa fazer com certa regularidade. Nesta lista, defina suas prioridades em ordem numérica e quanto tempo aplicará em cada uma delas (lembre-se: não existem duas prioridades 1). Dependendo de sua rotina, adicione uma linha com um número específico de horas para "eventualidades / imprevistos"). Feito isto vá somando o número de horas da lista de cima para baixo até atingir o limite que você considera razoável.

3. Competitividade ética e respeitosa: A competitividade nos é inerente nesta Casa, afinal, assim fomos selecionados, mas é fundamental mantê-la sob controle. Quando aplicada com ética e respeito pode ser uma excelente fonte de estímulo a todos os envolvidos. Lembre que antes de um potencial “adversário", esteja ele na quadra, na sala ou em qualquer outro lugar, estamos lidando com pessoas que devem ser tratadas dentro dos limites da ética e de forma respeitosa. Ganhe com seu talento e potencialidades e não com a desqualificação do adversário.

4. Explore a Universidade: Lembre-se que os tempos de colégio já eram! Jamais encare a Faculdade como um prolongamento do colégio. A coisa mais rica de uma Universidade é a diversidade de pessoas, saberes, atividades, possibilidades. Viva a Universidade por inteiro, o que ela tem dentro e fora das salas de aula, o que acontece nos prédios e fora deles. Lembre-se: na Universidade você tem a obrigação de adquirir uma formação técnica de qualidade, mas tem também a possibilidade de ampliar sua formação global, pessoal, cultural, etc.

5. Ouça seus veteranos: Eles sabem como ninguém como está o dia-a-dia e já têm alguma experiência pessoal e podem, com a motivação correta, ajudá-los bastante a compreender as diversas dificuldades que são enfrentadas na prática*. Apenas um cuidado: as opiniões servem como orientação para a sua decisão. Tenha certeza que seu interlocutor leva em conta o seu ponto de vista e não necessariamente tenta impor o dele.

6. Nada de direcionamento precoce: Você terá tempo para escolher sua especialidade ou área de atuação. Fazer isso

Tutor, fazendo parte do Programa Tutores FMUSP desde 2010 como tutor e nos anos de 2001 e 2002 como aluno. Graduado pela FMUSP, e com residência em Patologia, é professor do curso de Patologia Geral ( $2^{\circ}$ ano $)$ e faz pesquisa com Patologia Pulmonar e de Autópsia. Endereço para correspondência: Luiz Fernando Ferraz da Silva. Av. Dr. Arnaldo, 455 - Depto. de Patologia da FMUSP. São Paulo, SP. e-mail: burns@usp.br 
precocemente é um grande risco pois pode fazer com que você tenha um foco muito específico e isso embace a visão de todas as outras possibilidades.

7. Encare as disciplinas básicas com o enforque certo: Primeiro, elimine o preconceito de que o conhecimento básico é ruim. As disciplinas básicas são o alfabeto da medicina (você não pensa no alfabeto para transmitir uma mensagem, mas você o utiliza ainda que indiretamente, para isso). É isso que as básicas são e assim devem ser encaradas. Elas não são redações (casos clínicos), não são frases (diagnósticos), não são sequer palavras (exames, sinais ou sintomas), são apenas letras, mas sem letras não se fazem redações. Portanto, não crie a expectativa de que todas as matérias da Faculdade de Medicina têm interface médica direta, às vezes é preciso aprender a soletrar!

8. Estude bastante: O primeiro ano, repleto de disciplinas básicas, pode ser árduo e muitas vezes chato - um motivo ainda maior prá você estudar bem as matérias e se livrar disso de uma vez por todas. Se estudar isso uma vez pode ser chato, imagine ter que repetir.

9. Descubra seu jeito de estudar: Infelizmente (ou felizmente), o tempo das aulas extremamente didáticas e esquemáticas do colégio e do cursinho, já passou para vocês. A partir de agora, você terá que descobrir qual é a SUA melhor forma de estudo, os horários em que estuda melhor, seu grau de dependência de aulas teóricas, etc.. Apenas uma dica que eu considero universal - estude um pouco de cada vez. Deixar para estudar tudo na véspera da prova pode até resultar numa nota razoável, mas dificilmente resultará num aprendizado sólido e um aprendizado sólido hoje representará uma enorme economia de tempo de estudo nos próximos anos.

10. Não se esqueça da vida social - Sem apologia ao trabalho insano! A satisfação com sua vida profissional está diretamente ligada à saúde da sua vida social, da sua relação com as pessoas que você considera. $\mathrm{Na}$ Faculdade, tendemos a fechar o círculo de amizades neste contexto. Fuja desta armadilha enquanto é tempo! Crie as relações internas, no contexto da faculdade, mas também mantenha relações com as pessoas de fora do círculo (seus amigos de colégio, cursinho, de outras unidades ou universidades). Isso manterá sua mente e visão abertas em diversos sentidos, inclusive na habilidade de falar de outras coisas além de medicina.

11. Organize sua vida pessoal: Especialmente para aqueles que não moram com suas famílias, atividades quotidianas podem representar um desafio, como por exemplo, ir ao supermercado, ao banco ou preparar uma refeição. Por outro lado, esta é uma situação de aprendizado e crescimento muito grande, que não deve ser considerada um "peso", deve ser assumida com naturalidade (todos chegam a esta fase em algum momento), e deve ser incluída no seu cronograma de atividades como qualquer outra atividade prioritária.

12. Se ajudem, no bom sentido: Muitas vezes estudar ou rever a matéria junto com um colega, discutindo dúvidas e procurando respostas é uma excelente forma para se alcançar boa fixação dos conhecimentos e tornar o estudo mais divertido. Sem contar que o compromisso com o colega ajuda a organização e o planejamento evitando a procrastinação.

\footnotetext{
* Não posso deixar de fazer aqui um agradecimento à "minha veterana mais querida", a Tatiana Villas Boas Gabbi, por toda a sua ajuda, paciência e compreensão com este calouro que aqui escreve!
} 